\title{
Proposed methodology for monitoring antiretroviral drugs price negotiations in Latin America and the Caribbean
}

\author{
Claudia G. S. Osorio-de-Castro, ${ }^{1}$ Maruja Crisante, ${ }^{2}$ Elaine S. Miranda, ${ }^{1}$ \\ Egléubia A. Oliveira, ${ }^{1}$ and Maria A. Oliveira ${ }^{1}$
}

Suggested citation Osorio-de-Castro CGS, Crisante M, Miranda ES, Oliveira EA, Oliveira MA. Proposed methodology for monitoring antiretroviral drugs price negotiations in Latin America and the Caribbean. Rev Panam Salud Publica. 2009;26(2):137-47.

\begin{abstract}
Objectives. The spread of HIV/AIDS challenges governments to provide antiretroviral $(A R V)$ treatment at affordable prices, and various initiatives have been developed with that intent. In Latin America and the Caribbean, four subregional negotiations were conducted during 2002-2005 to reduce drug prices and thus broaden access to ARVs. Studies were carried out to monitor the negotiations, and the development of a monitoring methodology was recommended. The objective of the current study was to develop and describe a potential methodology for monitoring ARV price negotiations.

Methods. The study, carried out in 2006-2007, consisted of a design phase and validation phase. The design phase included an extensive literature review and development of a theoretical framework. Validation was performed using health professional consensus and pilot studies in three countries-Barbados, Honduras, and Peru-representing the Caribbean, Central American, and Andean subregions.

Results. The results included a detailed logic model and a 40-indicator framework. Both were tested in the field. Indicators were evaluated for feasibility, pertinence, and sensitivity, based on the outcome of the pilot study.

Conclusions. This monitoring methodology is designed to help countries self-evaluate progress toward implementation of ARV price negotiations. The results of the pilot study indicate that its implementation in the field helped elucidate the ARV price negotiation process by identifying local conditions and indirectly measuring countries' negotiating capacities.
\end{abstract}

Key words Anti-HIV agents; drug costs; national drug policy; Latin America; Caribbean Region.

1 Center for Pharmaceutical Policies (NAF), Sérgio Arouca National School of Public Health, Oswaldo Cruz Foundation (Fiocruz), Rio de Janeiro, RJ, Brazil. Send correspondence and reprint requests to Claudia Garcia Serpa Osorio-de-Castro, Senior Researcher, Núcleo de Assistência Farmacêutica, Escola Nacional de Saúde Pública, Fundação Oswaldo Cruz, Rua Leopoldo Bulhões 1480, Sala 625, Manguinhos, CEP 21041-210, Rio de Janeiro, RJ, Brazil; telephone: +55 21 2598-2763/2598-2591; fax: +55 21 2209-3076; e-mail: claudia.osorio@ensp. fiocruz.br

2 National Regulatory Agency for Medicines and Drugs (DIGEMID), Ministry of Health, Lima, Peru.
The spread of HIV/AIDS has challenged governments all over the world (1). The fight against the epidemic involves a multidimensional approach, which includes the treatment of people with AIDS (2). In this regard, the price of medicines, particularly the new, patented antiretrovirals (ARVs), has been affecting the capacity of governments and health systems to make them available for those in need $(3,4)$.
To improve the capacity of governments in providing ARVs and other AIDS-related medicines for various populations, several initiatives at the international level have been developed and implemented involving the pharmaceutical industry, not-for-profit foundations, nongovernmental organizations (NGOs), and multinational endeavors such as the Accelerating Access Initiative (AAI), the Clinton Foundation HIV / AIDS Initiative 
(CHAI), The Global Fund to Fight AIDS, Tuberculosis \& Malaria (GFATM) (5-9), and, more recently, the International Drug Purchase Facility (UNITAID) created by five countries in 2006 (10). At the national level, bilateral price negotiations with pharmaceutical companies, investment on local production, and use of flexibilities created under the World Trade Organization (WTO) Agreement on Trade-Related Aspects of Intellectual Property Rights (TRIPS) have been undertaken by various countries $(11,12)$.

At the regional level, pooled procurement and subregional negotiations are the main strategies that have been adopted by governments to promote price reduction $(8,13,14)$. For example, the Pan American Health Organization (PAHO) Strategic Fund, a mechanism created to promote access to quality essential public health supplies in the Americas, purchases medicines for HIV/AIDS, tuberculosis (TB), and malaria, in addition to various vaccines and biologicals. The Strategic Fund currently works in cooperation with 17 countries, offering technical cooperation and providing evaluation of national supply systems (9).

ARV price negotiations have developed into a subregional strategy for Latin America and the Caribbean. Caribbean and Central American countries participated in negotiations in 2002 and early 2003 through the AAI and achieved substantial reduction of ARV prices (13). In mid-2003, 10 more Latin American countries (Argentina, Bolivia, Chile, Colombia, Ecuador, Mexico, Paraguay, Peru, Uruguay, and Venezuela), innovative pharmaceutical companies, and generics manufacturers achieved significant price reductions through participation in the first round of ARV price negotiations for the North America, Andean, and Southern Cone subregions ("Round I"), held in Lima, Peru. In August 2005, a second round of subregional negotiations ("Round $\mathrm{II}^{\prime}$ ), including the 10 original country participants plus Brazil, was held in Buenos Aires, Argentina, in an effort to achieve further price reductions. This effort proved largely successful, resulting in prices 15 to $55 \%$ lower (per treatment line) than those agreed upon in the first round of negotiations (15).

Despite these successes, studies conducted to measure the impact of Round I on the actual pricing of procured medicine $(16,17)$ showed that the negotiated prices were rarely implemented. For example, although countries that participated in Round I had obtained reference-level pricing (the lowest negotiated price for each ARV) only five items were actually procured at prices equal to or less than the reference prices. Countries ultimately purchased ARVs at prices that were, on average, $165.4 \%$ above the reference range. Constraints included legal frameworks incompatible with the negotiated technical and administrative conditions, and lack of adherence to the negotiated conditions by some manufacturers (8).

By the end of Round II, participants had reached consensus on the need for countries to monitor the implementation of prices obtained through current and future negotiations. The ARV Negotiation Monitoring Group (Grupo de Acompañamiento de las Negociaciones de Antiretrovirales, GAN/ARV), created by country participants to monitor Round II, proposed the idea of developing and testing a specific methodology for this purpose.

Within this context, a methodology was developed by the Center for Pharmaceutical Policies at the Oswaldo Cruz Foundation (Fiocruz) Sérgio Arouca National School of Public Health (NAF/ ENSP) in Rio de Janeiro, within the scope of a joint initiative between NAF/ ENSP, the Joint United Nations Programme on HIV/AIDS (UNAIDS), and the French Ministry of Foreign Affairs.

\section{MATERIALS AND METHODS}

The overall objective of the methodology is to expand countries' focus beyond ARV prices per se to include the negotiation process as a whole, and any related country requirements (e.g., market authorization rules and manufacturing standards), in order to achieve more successful and tangible long-term outcomes. The research, carried out in 2006-2007, consisted of a design phase and a validation phase.

The design phase began with a review of the literature and documents related to previous price negotiations. Once the context variables related to the process of price negotiation and implementation were identified and described, a theoretical framework was developed and a logic model constructed. The logic model includes inputs (resources), activities, products, results, and impacts (18) and is organized to demonstrate which variables interact to produce the expected outcomes. Based on this model, 40 indicators and various authoritative data sources were identified and compiled. The indicator framework and key data sources are intended for use in assessments of the ARV price negotiation process and to contribute to the development of optimal data collection instruments and methods.

The validation phase was performed in two steps: health professional consensus and pilot studies. The first step consisted of discussions with various professionals selected according to the following criteria: experience in management of country programs supplying ARVs, or pooled procurement schemes; previous participation in the ARV price negotiation process; and experience in impact evaluation of price negotiation processes. This part of the research was developed with the collaboration of PAHO/World Health Organization (WHO) Medicines Advisors and professionals within the Brazilian STD/AIDS Program, and the resulting recommendations were incorporated into both the theoretical and indicator frameworks.

The pilot study was performed in three countries: Barbados, Honduras, and Peru. These countries were selected based on certain characteristics qualifying them as representative of specific subregions (Caribbean, Central American, and Andean), and on their participation in different types of ARV price negotiation processes. In addition, all three countries were deemed to have good potential for reliable data collection based on previous contacts with key informants and local support from PAHO.

Data collection was conducted through semi-structured (open-format) interviews. Key actors included national drug regulatory agencies; the national entity responsible for overseeing intellectual property rights; national HIV / AIDS programs, including the departments responsible for ARV procurement; and incountry NGOs involved in procuring ARVs. Other country-specific data, such as procurement prices and regulations, were also identified and collected.

The data collected in the pilot studies allowed researchers to evaluate each of the proposed indicators based on three criteria: feasibility, pertinence, and sensitivity. Feasibility was estimated in terms of how rapidly and easily data was collected for specific indicators within each 
country context, and if the information source was adequate. Pertinence was estimated as a positive indicator attribute if the question was expressed correctly and if it permitted contributions from different viewpoints. Sensitivity was estimated as the capacity of the indicator to clearly separate a positive from a negative situation in each context. These parameters were initially evaluated for each country separately. A subsequent, overall analysis was conducted by a panel composed of all researchers participating in the study, who then reached consensus, allowing the group to obtain one single measure of indicator value.

In one of the three countries under study (Peru), additional analysis was conducted (e.g., determination of the weighted average of prices and the percent variation of prices vs. reference values) to verify if the proposed calculations for the quantitative indicators were adequate. These analyses were able to be carried out in Peru due to available data on procurement prices.

\section{RESULTS}

The results of this methodological development study are presented in the logic model (Figure 1), and the indicator framework (Table 1), which stems from the logic model and incorporates the evaluation of each indicator.

\section{Logic model}

The results of the literature review and the validation process support the elements displayed in the logic model.

Inputs were characterized as follows: demand for ARVs is the main aspect to consider as a starting point for the negotiation process. It stems from need, which may be defined as the number of patients that require treatment, based on treatment guidelines (19). Nevertheless, need must then be translated into a demand forecast, which is represented as ARV quantities, in accordance with budgetary constraints and supply (20-22).

The supply of medicine, on the other hand, is determined by market availability. For this component, the supply side is composed of companies authorized to manufacture and/or sell pharmaceuticals in the country, and the products themselves, which must have passed in-country registration procedures (i.e., market authorization). The number of suppliers determines the degree of competition and thus may reduce prices for a given product (4).

The characteristics of each country's pharmaceutical market are largely determined by the legal framework regulating requirements for market authorization and manufacturing practices; regulation of bioavailability and bioequivalence testing; commercial aspects, such as tariffs and taxes; intellectual property rights; and trade agreements. All of these mainly technical issues have a direct impact on price structure (23).

Financing sources and management of funds influence the way in which the procurement mechanisms are implemented. Problems arise when there are multiple financing sources coupled with uncoordinated management of resources, which may lead to diminished market power and negotiating capacity for buyers. Process transparency is mandatory, as are steps taken to guarantee the availability, quality, affordability, and sustainability of the medicine supply (14).

Additional inputs include national and regional negotiation mechanisms, which influence the capacity to negotiate price reductions at the country level, and various other stakeholders in the price negotiation process. In Latin America and the Caribbean, these have included the CHAI, the PAHO Strategic Fund, the International Dispensary Association (IDA), and the GFATM.

Three main, inter-related price negotiation activities (forecasting, procurement, and negotiation) and four products (ARV purchase quantity, procurement price, technical and commercial conditions, and the "ceiling" or maximum reference price) were identified in the construction of the logic model. The three activities and their resulting products are directly influenced in various degrees by multiple inputs (resources). Other activities that were not directly related to ARV price negotiation but could influence the process (e.g., medicines selection) were also theoretically explored but do not appear in the model.

Forecasting is linked to demand, supply, and budget, and thus influences ARV procurement (24). Difficulties in obtaining data on country budgets for ARVs may be a constraint when examining this activity. Furthermore, the actual quantities of ARVs to be purchased are sometimes considered privileged information by procurement departments.
Procurement is largely influenced by the negotiation process but is also affected by the actions of the stakeholders participating in the process, and the type of items being purchased. From the perspective of the buyer, a successful procurement outcome is one in which the desired items are procured, through negotiations with suppliers, at a price equal to or less than the maximum reference price. Countries' success in the negotiating process is thus determined not only by their capacity to buy ARVs at better prices but also by the commitment of suppliers to adhere to the negotiated standards (8).

The negotiation process is derived from the interaction between negotiation mechanisms, financing sources and market power, and the balance of supply and demand. Although it is influenced by both forecasting and procurement, the negotiation activity has a direct effect only on procurement. The negotiation process also determines the maximum reference price (which applies to a predetermined group of medicines, is only valid during a certain timeframe, and must adhere to in-country regulations), and the technical and commercial conditions to be agreed upon by suppliers and buyers (13).

Model results are generally directly measurable and short-term. Long-term success in price negotiations is measured by the extent of overall reductions in ARV prices, expressed as a change in price trends over time. Another positive and measurable impact is a rise in treatment coverage for people living with HIV / AIDS (PLWH).

\section{Indicator framework}

A framework of 40 indicators or benchmarks was developed to measure the components and relationships described by the logic model, and to explore data generated by it.

The indicators were divided into five main categories (inputs or resources, activities, products, results, and impacts) corresponding to the five main elements of the logic model. For example, the resource indicators are used to assess aspects related to demand, supply, the legal framework, financing, and negotiation mechanisms. The indicator framework does not represent every element of the logic model but is limited to those likely to have a direct effect on price negotia- 
FIGURE 1. Proposed logic model for monitoring antiretroviral (ARV) price negotiations in Latin American and Caribbean countries, developed in Brazil and tested in Barbados, Honduras, and Peru, 2006-2007

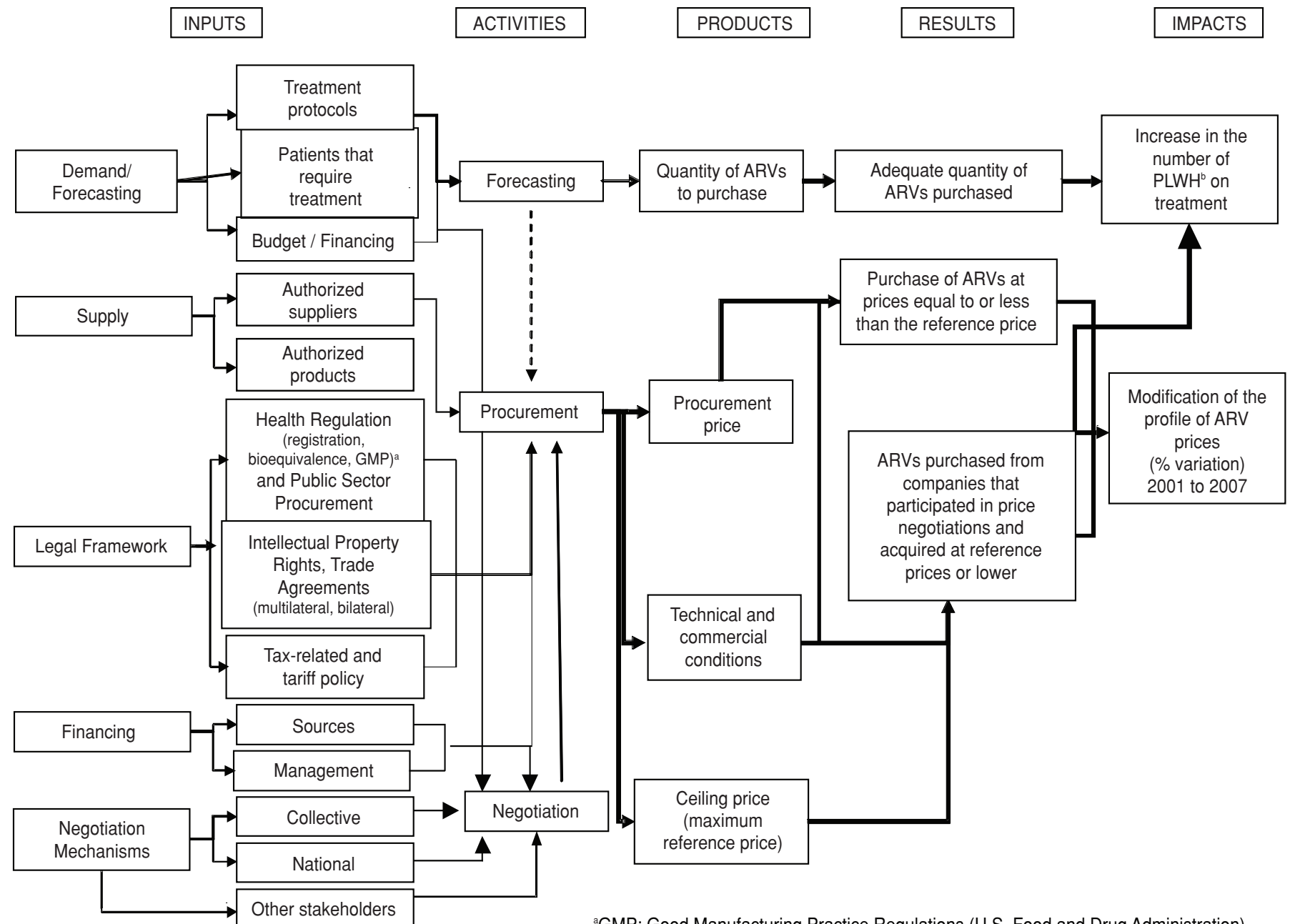

aGMP: Good Manufacturing Practice Regulations (U.S. Food and Drug Administration). 'PLWH: People living with HIV/AIDS.

tions. It also includes various elements required for evaluating the indicators (e.g., a detailed description of each indicator; key data sources; and the feasibility, pertinence, and sensitivity criteria).

The majority of indicators received medium to high scores for all three evaluation criteria. As expected, scores for feasibility were low for indicators depicting budget issues, patent protection, technical and commercial conditions, evaluation of procurement prices for non-negotiated ARVs, and price reduction over time. All indicators, with the exception of the one developed to measure variation of procurement prices for non-negotiated ARVs, were considered pertinent. Sensitivity evaluation resulted in low marks for patent protection and technical and commercial conditions indicators.

\section{DISCUSSION}

\section{Constraints}

The logic model is an adequate tool not only for describing price negotiation components but also for highlighting the relationships among them. It also outlines potential constraints specific to the ARV price negotiation process that may result if the functioning of the model's underlying theory is altered $(25,26)$.

For example, the ARV market has special characteristics and dynamics that can affect price reduction (27), such as competition from generic drug manufacturers, limited monitoring and availability of price information, and differential pricing (multiple prices for the same product). In low- and middle- income countries, where generic competition is firmly in place, the prices of ARV products from research and development (R\&D) companies may be lower. But in countries where generic competition is weak or nonexistent, prices for the same product will be higher (28).

Another limitation stems from special regulations imposed by the negotiating countries. For example, in some countries, manufacturing companies are prohibited from marketing medicines. Therefore, in order to implement any ceiling prices established in negotiations with those countries, pharmaceutical companies would need to obtain special marketing authorization. Selling the products through an intermediary entity is always a possibility but requires additional commercial agreements between 
TABLE 1. Proposed indicator framework for evaluating antiretroviral (ARV) price negotiations in Latin American and Caribbean countries, based on monitoring methodology developed in Brazil and tested in Barbados, Honduras, and Peru, 2006-2007

\begin{tabular}{|c|c|c|c|c|c|}
\hline \multirow[b]{2}{*}{ Indicator } & \multirow[b]{2}{*}{ Details } & \multirow[b]{2}{*}{ Source } & \multicolumn{3}{|c|}{ Evaluation criteria } \\
\hline & & & Feasibility & Pertinence & Sensitivity \\
\hline \multicolumn{6}{|l|}{ Component: Demand } \\
\hline $\begin{array}{l}\text { Existence of treatment guidelines for } \\
\text { HIV/AIDS enforced in the country }\end{array}$ & $\begin{array}{l}\text { Existence of treatment guidelines approved by the } \\
\text { Ministry of Health and in force in the country }\end{array}$ & National HIV/AIDS Program & High & Yes & High \\
\hline $\begin{array}{l}\text { Budget annually allocated for } \\
\text { purchase of ARVs }\end{array}$ & $\begin{array}{l}\text { Amount allocated in official budget for sectors } \\
\text { that purchase ARV medications }\end{array}$ & National HIV/AIDS Program & Medium & Yes & Medium \\
\hline $\begin{array}{l}\text { Budget annually allocated for } \\
\text { purchase of ARVs per patient and } \\
\text { line of treatment }\end{array}$ & $\begin{array}{l}\text { Amount allocated per patient and line of } \\
\text { treatment }\end{array}$ & National HIV/AIDS Program & Low & Yes & Medium \\
\hline $\begin{array}{l}\text { Number of pharmaceutical } \\
\text { companies authorized to } \\
\text { manufacture, import, and market } \\
\text { ARV medicines included in } \\
\text { Essential Medicines List (EML) or } \\
\text { treatment protocols }\end{array}$ & $\begin{array}{l}\text { Number of companies with permission from } \\
\text { health authority to manufacture, import, or market } \\
\text { ARV medicines included in the national EML or } \\
\text { treatment protocols in the country }\end{array}$ & DRA & Medium & Yes & Medium \\
\hline $\begin{array}{l}\text { Percentage of ARVs registered in } \\
\text { the country produced by } \\
\text { manufacturers involved in price } \\
\text { negotiations }\end{array}$ & $\begin{array}{l}\text { Percentage of ARV medicines with market } \\
\text { approval from country health authority and } \\
\text { produced by manufacturers involved in price } \\
\text { negotiations }\end{array}$ & DRA & Medium & Yes & Medium \\
\hline $\begin{array}{l}\text { Percentage of ARVs in EML or } \\
\text { treatment protocols under patent } \\
\text { protection }\end{array}$ & $\begin{array}{l}\text { Percentage of ARV medicines included in the } \\
\text { national EML or official treatment guidelines that } \\
\text { are under patent protection }\end{array}$ & DRA/Patent Office & Low & Yes & Low \\
\hline \multicolumn{6}{|l|}{ Component: Legal Framework } \\
\hline $\begin{array}{l}\text { Health authority approval is required } \\
\text { for importing and marketing } \\
\text { medicines }\end{array}$ & $\begin{array}{l}\text { Health authority approval is required in the } \\
\text { country for marketing and importing medicines }\end{array}$ & DRA/legal base & High & Yes & Medium \\
\hline $\begin{array}{l}\text { Country representation is required } \\
\text { for medicine supplier companies }\end{array}$ & $\begin{array}{l}\text { Legal representation of supplier is required in the } \\
\text { country for marketing and importing medicines }\end{array}$ & DRA/legal base & High & Yes & Medium \\
\hline Regulation of ARV prices & $\begin{array}{l}\text { Existence of specific price regulation } \\
\text { mechanisms that involve ARV medicines }\end{array}$ & DRA/legal base & High & Yes & High \\
\hline $\begin{array}{l}\text { Requirement of bioequivalence for } \\
\text { marketing approval by the health } \\
\text { authority }\end{array}$ & $\begin{array}{l}\text { Bioequivalence studies are required to grant } \\
\text { marketing approval by the health authority for } \\
\text { ARV medicines manufactured in the country or } \\
\text { imported }\end{array}$ & DRA/legal base & High & Yes & High \\
\hline $\begin{array}{l}\text { Requirement of bioequivalence in } \\
\text { the procurement process }\end{array}$ & $\begin{array}{l}\text { Requirement of bioequivalence studies in the } \\
\text { procurement process in the case of countries that } \\
\text { do not require them in order to obtain health } \\
\text { authority approval for ARV medicines } \\
\text { manufactured in the country or imported }\end{array}$ & $\begin{array}{l}\text { DRA/legal base/ } \\
\text { procurement unit (logistics) }\end{array}$ & High & Yes & High \\
\hline $\begin{array}{l}\text { Requirement of compliance to Good } \\
\text { Manufacturing Practices (GMP) }\end{array}$ & $\begin{array}{l}\text { Existence of GMP requirements for } \\
\text { manufacturers within the country or for } \\
\text { manufacturers of imported medicines }\end{array}$ & $\begin{array}{l}\text { DRA/legal base/ } \\
\text { procurement unit (logistics) }\end{array}$ & High & Yes & High \\
\hline
\end{tabular}


TABLE 1. (Continuation)

\begin{tabular}{|c|c|c|c|c|c|}
\hline \multirow[b]{2}{*}{ Indicator } & \multirow[b]{2}{*}{ Details } & \multirow[b]{2}{*}{ Source } & \multicolumn{3}{|c|}{ Evaluation criteria } \\
\hline & & & Feasibility & Pertinence & Sensitivity \\
\hline $\begin{array}{l}\text { Incorporation of Trade-Related } \\
\text { Aspects of Intellectual Property } \\
\text { Rights (TRIPS) Agreement into } \\
\text { national legislation }\end{array}$ & $\begin{array}{l}\text { Parallel importation, "Bolar" provision, } \\
\text { compulsory licensing, participation by the } \\
\text { Ministry of Health in analysis of the } \\
\text { pharmaceutical industry patent claims }\end{array}$ & $\begin{array}{l}\text { Ministry of Health/DRA/ } \\
\text { legal base }\end{array}$ & High & Yes & High \\
\hline Data exclusivity & $\begin{array}{l}\text { Existence of protection of data presented for } \\
\text { the originator medicine to the DRA (through a } \\
\text { trade agreement clause or some other } \\
\text { agreement) that specifies the length of } \\
\text { protection and any related technical } \\
\text { requirements (type of molecule, etc.) }\end{array}$ & $\begin{array}{l}\text { Ministry of Health/DRA/ } \\
\text { legal base }\end{array}$ & High & Yes & High \\
\hline $\begin{array}{l}\text { Existence of trade agreements } \\
\text { signed at global, regional, or } \\
\text { bilateral level }\end{array}$ & $\begin{array}{l}\text { Existence of bilateral, regional, or multilateral } \\
\text { trade agreements that incorporate TRIPS-plus } \\
\text { provisions (e.g., data exclusivity, extension of the } \\
\text { patent term, linkage between health authority } \\
\text { approval and patent status) specifying the } \\
\text { agreement's country signatories and } \\
\text { incorporation into national legislation }\end{array}$ & $\begin{array}{l}\text { Ministry of Health/DRA/ } \\
\text { legal base }\end{array}$ & High & Yes & High \\
\hline $\begin{array}{l}\text { Existence of tax-related and/or tariff } \\
\text { policies for ARVs }\end{array}$ & $\begin{array}{l}\text { Existence of a policy for importation and } \\
\text { marketing of ARV medicines (involving tariffs and } \\
\text { taxes, etc.) }\end{array}$ & $\begin{array}{l}\text { DRA/legal base/ } \\
\text { procurement unit } \\
\text { (logistics) }\end{array}$ & Medium & Yes & High \\
\hline \multicolumn{6}{|l|}{ Component: Financing } \\
\hline $\begin{array}{l}\text { Financing sources for ARV medicine } \\
\text { coverage }\end{array}$ & $\begin{array}{l}\text { Public funds, social security, Global Fund to Fight } \\
\text { AIDS, Tuberculosis \& Malaria (GFATM), out-of- } \\
\text { pocket payment, etc. }\end{array}$ & National HIV/AIDS Program & High & Yes & High \\
\hline $\begin{array}{l}\text { Public sector expenditures per year } \\
\text { on ARV medicines as portion of } \\
\text { total public expenditure on } \\
\text { medicines }\end{array}$ & $\begin{array}{l}\text { Public sector spending on ARV medicines as a } \\
\text { portion of all expenditures for medicines }\end{array}$ & $\begin{array}{l}\text { National HIV/AIDS Program/ } \\
\text { procurement unit (logistics) }\end{array}$ & Medium & Yes & Medium \\
\hline $\begin{array}{l}\text { Level of centralization for managing } \\
\text { financial resources in health } \\
\text { sector }\end{array}$ & $\begin{array}{l}\text { Two distinct possibilities: centralized or } \\
\text { decentralized management of funds }\end{array}$ & National HIV/AIDS Program & High & Yes & High \\
\hline \multicolumn{6}{|l|}{ Component: Negotiation mechanisms } \\
\hline $\begin{array}{l}\text { Participation in ARV price } \\
\text { negotiation processes in Latin } \\
\text { America or Caribbean }\end{array}$ & $\begin{array}{l}\text { Participation in local or other negotiation } \\
\text { processes, describing the institutions that } \\
\text { participated (e.g., Ministry of Health, Social } \\
\text { Security, private sector, NGOs, etc.) and } \\
\text { negotiation methods }\end{array}$ & $\begin{array}{l}\text { Ministry of Health/National } \\
\text { HIV/AIDS Program/DRA }\end{array}$ & High & Yes & High \\
\hline $\begin{array}{l}\text { Directing ARV price negotiation } \\
\text { processes at the national level }\end{array}$ & $\begin{array}{l}\text { Directing internal negotiation processes with } \\
\text { pharmaceutical companies operating inside the } \\
\text { country }\end{array}$ & $\begin{array}{l}\text { Ministry of Health/National } \\
\text { HIV/AIDS Program/DRA }\end{array}$ & High & Yes & High \\
\hline $\begin{array}{l}\text { Existence of agreements for ARV } \\
\text { procurement with the participation } \\
\text { of international organizations }\end{array}$ & $\begin{array}{l}\text { Participating in ARV procurement process } \\
\text { through initiatives such as the Clinton } \\
\text { Foundation, GFATM, PAHO Strategic Fund }\end{array}$ & $\begin{array}{l}\text { Ministry of Health/National } \\
\text { HIVIAIDS Program/DRA }\end{array}$ & High & Yes & High \\
\hline \multicolumn{6}{|l|}{ Component: Negotiation process } \\
\hline $\begin{array}{l}\text { Participation of technical and political } \\
\text { sector authorities (regulatory, } \\
\text { planning, judicial) in negotiations }\end{array}$ & $\begin{array}{l}\text { Verifying the relationship between those selected } \\
\text { to participate in the negotiation process with } \\
\text { regard to their job titles and responsibilities }\end{array}$ & Interview with stakeholders & Medium & Yes & Medium \\
\hline $\begin{array}{l}\text { Participation of PLWH (People Living } \\
\text { With HIVIAIDS) representatives in } \\
\text { ARV negotiation processes } \\
\text { (collective or national) }\end{array}$ & $\begin{array}{l}\text { Public interest non-governmental organizations } \\
\text { (NGOs) that participated in the negotiation } \\
\text { process }\end{array}$ & Interview with stakeholders & High & Yes & High \\
\hline \multicolumn{6}{|l|}{ Component: Procurement process } \\
\hline $\begin{array}{l}\text { Existence of minimum technical } \\
\text { requirements and specifications } \\
\text { for ARV medicine procurement }\end{array}$ & $\begin{array}{l}\text { Verification that the minimum technical } \\
\text { requirements and specifications are being } \\
\text { enforced in the purchasing process (based on } \\
\text { reference standards for quality aspects, minimum } \\
\text { implementation, GMP, and Good Production } \\
\text { Practices (GPP), among others) }\end{array}$ & $\begin{array}{l}\text { National HIV/AIDS Program/ } \\
\text { Logistics office/ } \\
\text { representative from the } \\
\text { purchasing committee }\end{array}$ & High & Yes & (continued) \\
\hline
\end{tabular}


TABLE 1. (Continuation)

\begin{tabular}{|c|c|c|c|c|c|}
\hline \multirow[b]{2}{*}{ Indicator } & \multirow[b]{2}{*}{ Details } & \multirow[b]{2}{*}{ Source } & \multicolumn{3}{|c|}{ Evaluation criteria } \\
\hline & & & Feasibility & Pertinence & Sensitivity \\
\hline $\begin{array}{l}\text { Development of technical spread- } \\
\text { sheet on ARV reference prices }\end{array}$ & $\begin{array}{l}\text { Procurement units use the ARV and reagent } \\
\text { prices from the negotiations to develop a } \\
\text { spreadsheet of reference prices }\end{array}$ & $\begin{array}{l}\text { Logistics office/ } \\
\text { representative from the } \\
\text { purchasing committee }\end{array}$ & High & Yes & High \\
\hline $\begin{array}{l}\text { Percentage of total ARVs procured } \\
\text { through public tendering }\end{array}$ & $\begin{array}{l}\text { Percentage of the total amount of ARVs procured } \\
\text { each year through public tendering }\end{array}$ & $\begin{array}{l}\text { Logistics office/ } \\
\text { representative from the } \\
\text { purchasing committee }\end{array}$ & High & Yes & High \\
\hline \multicolumn{6}{|c|}{ Component: Defined quantity of ARV medicines to purchase } \\
\hline $\begin{array}{l}\text { Existence of yearly forecasting for } \\
\text { ARV medicines }\end{array}$ & $\begin{array}{l}\text { Official document released by a technical unit } \\
\text { with ARV medicine forecast }\end{array}$ & National HIV/AIDS Program & Medium & Yes & Medium \\
\hline \multicolumn{6}{|c|}{ Component: Ceiling prices (maximum reference prices) } \\
\hline $\begin{array}{l}\text { Percentage of ARV medicines and } \\
\text { reagents achieving reference } \\
\text { prices in price negotiations }\end{array}$ & $\begin{array}{l}\text { Percentage of ARV medicines and reagents } \\
\text { included in the negotiations that obtained } \\
\text { effective reference prices for a predetermined } \\
\text { period of time }\end{array}$ & $\begin{array}{l}\text { National HIV/AIDS program/ } \\
\text { reference documents/ local } \\
\text { negotiation processes }\end{array}$ & Medium & Yes & Medium \\
\hline \multicolumn{6}{|c|}{ Component: Technical and commercial conditions } \\
\hline $\begin{array}{l}\text { Technical and commercial } \\
\text { conditions employed in the } \\
\text { procurement process }\end{array}$ & $\begin{array}{l}\text { Negotiable and non-negotiable technical } \\
\text { conditions (e.g., companies with GMP, World } \\
\text { Health Organization (WHO) pre-qualified } \\
\text { products, bioequivalence, etc.) and commercial } \\
\text { conditions (type of price, extension period, etc.) }\end{array}$ & $\begin{array}{l}\text { Logistics office/ } \\
\text { representative from the } \\
\text { procurement committee/ } \\
\text { reference documents }\end{array}$ & Low & Yes & Low \\
\hline \multicolumn{6}{|l|}{ Component: Procurement price } \\
\hline $\begin{array}{l}\text { a) Median ARV medicine prices } \\
\text { b) Weighted average of ARV prices } \\
\text { c) Price of largest volume purchased } \\
\text { d) Cost/patient/year }\end{array}$ & $\begin{array}{l}\text { Method of analysis used by each country when } \\
\text { purchasing time frame is not on yearly basis } \\
\text { (expressed as any of the listed options) }\end{array}$ & $\begin{array}{l}\text { Logistics office/procurement } \\
\text { process documents }\end{array}$ & High & Yes & High \\
\hline \multicolumn{6}{|c|}{ Component: ARVs purchased at prices equal to or less than those established in negotiations } \\
\hline $\begin{array}{l}\text { Percentage of mean variation of } \\
\text { actual procurement prices vs. } \\
\text { negotiated prices }\end{array}$ & $\begin{array}{l}\text { The mean percentage of price variation for } \\
\text { purchased ARVs (i.e., the relationship between } \\
\text { actual procurement prices and the negotiated } \\
\text { prices) }\end{array}$ & $\begin{array}{l}\text { Collected price and supplier } \\
\text { data }\end{array}$ & Medium & Yes & High \\
\hline $\begin{array}{l}\text { Percentage of variation of actual } \\
\text { procurement price vs. lowest } \\
\text { regional price (median) for non- } \\
\text { negotiated ARVs }\end{array}$ & $\begin{array}{l}\text { Percent variation of actual procurement prices of } \\
\text { ARVs in relation to lowest regional price } \\
\text { (obtained from the median of the price } \\
\text { distribution) in the case of ARVs that were not } \\
\text { covered in the negotiation process }\end{array}$ & $\begin{array}{l}\text { Collected price and supplier } \\
\text { data }\end{array}$ & Low & Yes/No & High \\
\hline \multicolumn{6}{|c|}{ Component: ARVs purchased from companies that participated in price negotiations at prices equal to or lower than the negotiated prices } \\
\hline $\begin{array}{l}\text { ARVs purchased from companies } \\
\text { that participated in the negotiation }\end{array}$ & $\begin{array}{l}\text { Establishing which ARVs were procured from } \\
\text { companies that settled for supply after the } \\
\text { negotiation }\end{array}$ & Collected data & Medium & Yes & High \\
\hline $\begin{array}{l}\text { Percentage of mean variation in } \\
\text { purchasing prices offered by } \\
\text { supplier vs. prices offered in the } \\
\text { negotiations }\end{array}$ & $\begin{array}{l}\text { Verifying the prices offered for national } \\
\text { procurement vs. the prices offered by each } \\
\text { company in the negotiation process }\end{array}$ & Collected data & Medium & Yes & High \\
\hline \multicolumn{6}{|c|}{ Component: Modification of ARV price profile (\% variation) in Latin America and the Caribbean, 2001-2006 } \\
\hline $\begin{array}{l}\text { Differential in price reduction of ARV } \\
\text { medicines from 2001-2006 }\end{array}$ & $\begin{array}{l}\text { Verifying procurement price by medicine in the } \\
\text { country during the given period }\end{array}$ & $\begin{array}{l}\text { Observatory of ARV } \\
\text { medicine prices, Oregon } \\
\text { State University (OSU) } \\
\text { Report, Center for } \\
\text { Pharmaceutical Policies } \\
\text { (NAF)/Pan American Health } \\
\text { Organization (PAHO), } \\
\text { collected data }\end{array}$ & Low & Yes & High \\
\hline
\end{tabular}

Source: Authors' compilation. 
the company and the third party in order to comply with country regulations. This limitation would have a direct effect on the post-negotiation offer of ARVs at reference prices (8).

In addition, some drug products may not be market-authorized (regardless of any general marketing authorization obtained by the manufacturer). Lack of market authorization may be linked to countries' registration procedures, patent protection, commercial constraints, or faulty compliance with import duties. Therefore, participants in ARV price negotiations must ensure that the medicines being procured are authorized for import and marketing in the participating countries. Waivers specifically designed to help Ministries of Health gain import authorization for WHO-prequalified medicines can be obtained (29).

Other constraints to the ARV price negotiation process may stem from companies' internal policies. For example, some companies may not partake in public tendering in the negotiating countries due to a lack of commercial interest, or if agreements such as those described above, for third-party marketing of their products, are already in place (30). Another major disincentive to pharmaceutical companies' participation in ARV price negotiations is the fact that countries are not bound to buy exclusively from negotiation participants, regardless of any agreements that may result from the price negotiation process. In addition, other companies producing the same product but not participating in the price negotiations are not expected to adhere to any reference prices that are established. In these cases, companies may be unwilling or unable to participate in any price negotiations that would obligate them to sell their products at reference pricing.

All of the above imply that actual ARV post-negotiation buying prices may or may not be based on the established ceiling price. Constraints to actual implementation of price negotiations also emerge when countries' needs become urgent, precluding their ability to enforce ceiling prices.

The findings of this study suggest it is feasible to monitor price modification over time, within each country, and thus measure the impact of the negotiation process. In addition to the potential constraints on supply, a wide range of determinants (that will not be addressed in this paper) may develop over time with regard to demand. This includes the expected increase in the number of PLWH receiving treatment, changes in health system organization that may affect coverage, and the level of financial and institutional sustainability (31).

A final constraint was the low variability of indicator outcomes. While the model's supply subcomponent helps capture a general view of the ARV market and its relationship with health needs, and allows for an overall view of the level of participation of negotiating companies, the low variability of answers is apt to result in low or medium sensitivity for the indicators. Lack of available country information on any of the abovementioned issues affecting price negotiations is another potential constraint.

\section{Use of indicators}

Measuring demand helps establish a level of consistency between needs, forecasting, and technical requirements related to treatment, official policy (as expressed by protocols and national medicines lists (24)), and budget. However, obtaining the necessary data may not always be easy. For example, most country systems do not provide information on available budgets. Therefore, to mitigate the problem of paucity or lack of available data and make the best use of the indicators developed in the current study, very specific questions should be posed about operational definitions of "information systems," and treatment protocols (including treatment criteria and treatment options for adults, children, and pregnant women). Availability of these types of data is strongly affected by the level of in-country transparency of information, reinforcing the need for self-application of the methodology by countries, and the importance of maintaining consistency of data between different country sectors.

The national legal framework is another important factor requiring careful consideration due to its impact on a country's ability to effectively negotiate and procure ARVs. Technical barriers related to any quality assurance that countries may be carrying out, and legal and commercial constraints restricting access to pharmaceutical markets, can greatly influence the level of competition (8). Patents presented difficulties in all countries participating in the pilot study, often due to a lack of understanding of their importance on the part of health officials-and of health sector needs on the part of patent authorities (32). The high feasibility achieved nonetheless throughout most of the logic model's legal framework component is due to the ease with which country-specific market authorization can be outlined in detail.

Financing is an important component-and one that presents difficulties in terms of data collection. Most obtainable information is fragmented or qualitative: specific, quantitative financing information is scarce, confirming assumptions made during the development of the logic model. Nevertheless, keeping the indicators simple and straightforward can heighten their value. Seeking financing information provides an additional benefit by identifying stakeholders that are able to apply negotiation mechanisms.

The indicators for measuring negotiation mechanisms are sensitive for measuring countries' negotiation capacity (i.e., how capacity-building for negotiations is developed). In addition, they are valuable in drawing out experiences and lessons learned-important information for sharing across countries $(14,28)$. One problem with this set of indicators, however, was the difficulty in determining one standard definition for "national negotiations" across the pilot countries.

The negotiation process indicators help identify stakeholders with the capacity to apply the negotiation mechanisms, and their specific role-important information for this component (particularly in regard to NGOs). Likewise, the procurement process indicators allow for better understanding of critical aspects pertaining to technical issues, the setting of reference prices, and policies concerning procurement management (e.g., zero- or low-disclosure policies).

The indicator for determining ARV procurement quantities is based on estimates (annual forecasting by government agencies). The results of this indicator should thus be interpreted with caution. It should be noted that the existence of procurement procedures per se does not ensure the overall quality of the process (21). Although the procurement process indicators are designed to assess some aspects of quality, based on predetermined technical standards and specifications, they may not draw out all inherent weaknesses in the system. 
While the ceiling price indicator highlights the tangible outcome (the maximum reference price), the variable related to technical and commercial conditions helps clarify countries' negotiation skills and strategies. For example, government stakeholders may influence the negotiation process by establishing stringent technical and commercial conditions (33) to guide negotiations and subsequent procurement (e.g., defining what is and what is not acceptable in terms of product specification and quality, delivery conditions, and other contract matters).

The procurement pricing and supplier indicators must be closely scrutinized over time. Depending on the availability of data and previously mentioned descriptive analysis methods, variability and thus sensitivity may vary from country to country. The best (i.e., recommended) method for price analysis is based on a weighted average of ARV prices. Using weighted averages allows for the inclusion of extreme scores. This type of data is dependent on price as well as quantity purchased (but is less dependent than the median on the number of events). Weighted averages may reflect the overall effect of negotiated prices on country purchasing performance. If there are no available data on quantities purchased, use of the price median is recommended.

It should be noted that 1) the use of the lowest regional price in the indicator that addresses the percent variation of the actual ARV procurement price versus the lowest regional price (median) requires regional data (28), and 2) the component examining the purchase of ARVs at reference pricing or lower from companies who participated in negotiations expresses the companies' degree of interest (participation and commitment).

The impact-measurement component ("modification of the ARV price profile"), which includes only one indicator, requires countries to collect pricing and procurement data over time. This would have a direct, positive effect on the availability of this type of data, which was found to be lacking in the current study (e.g., none of the countries participating in the pilot study had sufficient available data to permit a broad calculation of ARV pricing and procurement over time). This type of evaluation could be a first step in many countries to overcome this shortfall.
In general, the low scores given to specific indicators were attributed to lack of in-country information and/or high procurement standards. Budget data is a sensitive issue, and the prices that were actually paid are not easily disclosed. Technical and commercial conditions are also sensitive topics. Seoane-Vazquez and Rodriguez-Monguio (8) observed these same issues and implied their resolution was crucial for successful negotiations.

As mentioned above, along with technical and commercial conditions, the issue of patents emerged as problematic, with the associated indicator receiving low scores in feasibility as well as sensitivity. Patents are a subject to which countries must dedicate considerable time and effort due to various complexities related to patent claims and how they are described. Knowledge about patents remains extremely privileged, restricted to specialists in the field. This lack of widespread knowledge may help explain why patent-related aspects were under-appreciated as a determinant of outcomes in the negotiation process, even in Peru (which had the best availability of data among the three countries participating in the pilot study).

\section{Limitations}

One specific limitation of the methodology is the fact that neither the logic model nor the indicator framework focuses specifically on the pharmaceutical market or industry $(12,27)$. Because pharmaceutical manufacturers and markets vary across countries, it was decided that country-specific information pertaining to pharmaceutical markets should be added by country, along with the collected information, to maintain model consistency.

Another limitation was the lack of standardization in data collection. Although there was sufficient available information in all countries studied (despite the wide range in information disclosure), and the majority of indicators were thus easily answerable, it was difficult to ensure the collection of the same type of data across countries. In the future implementation of this methodology, it is important for each country to define the exact scope of each indicator, to avoid misunderstanding as to what type of data is needed. It is also important to determine who the stakeholders are, where to find them, and the best means of gathering information from them. In the current study, interviewees were asked to comment on a variety of topics in open-format interviews in order to capture a wide range of viewpoints and determine any areas of controversy.

As mentioned above, certain types of information, such as financing data and prices, were difficult to obtain (and in some situations, unobtainable). The current methodology was useful in identifying these information "black holes" and inconsistencies. For example, study results indicated the time needed to obtain data will vary between countries and is largely dependent on transparency and availability of information. One means of overcoming this constraint is the use of online information from international sources (34-36). However, these sources may not be comprehensive (e.g., they may not include all purchases made by a country during a given period, or all lines of financing and/or treatment). Nonetheless, in the absence of information produced by the country, this type of data can be useful.

\section{Conclusions}

The logic model provides a comprehensive picture of the main elements involved in the ARV price negotiation process and is therefore advantageous to other evaluation methodologies previously tested and published. Combining the logic model with the indicator framework ensures consistency in the evaluation results and allows for the identification of priority areas for intervention. Moreover, it results in a limited number of indicators, simplifying data collection and analysis.

Use of this methodology would allow countries to establish internal data banks that could be updated regularly. If adopted in more than one country, it would also allow for comparative analyses of prices for different periods of time and different suppliers and countries, as well as evaluation of supplier participation in the negotiation processes at national or subregional levels, generating more data-and thus increasing knowledge-about country- and regionspecific needs and conditions. This type of knowledge is generally considered a prerequisite for the development of effective price negotiation strategies, as it allows for the identification of local experiences that could be disseminated as 
lessons learned, and indirect measurement of country negotiating capacities, ultimately providing a feasible and useful framework for monitoring implementation of price negotiations.
The results of the pilot studies indicate that the application of the proposed monitoring methodology in Latin American and Caribbean countries is both feasible and useful. Its adoption in the

\section{REFERENCES}

1. Kallings LO. The first postmodern pandemic: 25 years of HIV/AIDS. J Intern Med. 2008; 263(3):218-43.

2. United Nations. Declaration of Commitment on HIV/AIDS 2001. United Nations General Assembly Special Session on HIV/AIDS. New York: UN; 2001 [cited 2008 May 10]. Available from: http://data.unaids.org/publications/ irc-pub03/aidsdeclaration_en. pdf.

3. Ford N, Wilson D, Costa Chaves C, Lotrowska M, Kijtiwatchakul K. Sustaining access to antiretroviral therapy in the less-developed world: lessons from Brazil and Thailand. AIDS. 2007;21 Suppl 4:S21-9.

4. Chirac P, Von Schoen-Angerer T, Kasper T, Ford N. AIDS: patent rights versus patient's rights. Lancet. 2000;356(9228):502.

5. World Health Organization; Joint United Nations Program on HIV/AIDS. Accelerating Access Initiative. Widening access to care and support for people living with HIV/AIDS. Progress report 2002. Geneva: WHO/UNAIDS; 2002.

6. William J Clinton Foundation. 2006 Annual Report. New York: WJCF; 2007 [cited 2007 Oct 9]. Available from: http://www.clinton foundation.org/about-the-clinton-foundation/ annual-financial-reports.

7. theglobalfund.org [Internet]. Geneva: GFATM; c2002-2009 [cited 2007 Oct 9]. Available from: http://www.theglobal fund.org/en/.

8. Seoane-Vazquez E, Rodriguez-Monguio R. Negotiating antiretroviral drug prices: the experience of the Andean countries. Health Policy Plan. 2007;22(2):63-72. Epub 2007 Feb 13.

9. Organização Pan-americana da Saúde; Organização Mundial da Saúde. $45^{\circ}$ Conselho Diretor. 56 ${ }^{\mathrm{a}}$ Sessão do Comitê Regional. Washington: PAHO/WHO; 2004 [cited 2008 Apr 5]. Available from: www.ops-oms.org/ portuguese/gov/cd/cd45-10-p.pdf.

10. Bermudez J. UNITAID: innovative financing to scale-up access to medicines. In: Global Forum update on research for health: fostering innovation for global health. Vol. 5. Woodbridge (UK): Pro-Brook Publishing; 2008. p. 184-5.

11. Chaves GC, Oliveira MA. A proposal for measuring the degree of public health-sensitivity of patent legislation in the context of the WTO TRIPS Agreement. Bull World Health Organ. 2007;85(1):49-56.

12. Westerhaus M, Castro A. How do intellectual property law and international trade agreements affect access to antiretroviral therapy? PLoS Med. 2006;3(8):e332.

13. Fitzgerald J, Gomez, B. An open competition model for regional price negotiations yields lowest ARV prices in the Americas. Presentation to the 8th World STI/AIDS Congress, Punta del Este (Uruguay), December 2-5, 2003. Available from: www.paho.org/English/ AD/FCH/AI/PriceNeg.pdf.
14. World Health Organization. Multi-country regional pooled procurement of medicines. Identifying key principles for enabling regional pooled procurement and a framework for inter-regional collaboration in the African, Caribbean and Pacific Island Countries. Geneva, Switzerland, 15-17 January 2007 [meeting report]. Geneva: WHO; 2007.

15. Organización Panamericana de la Salud; Ministerio de Salud y Ambiente de la Nación (AR). Países Latinoamericanos logran descuentos de hasta $55 \%$ en tratamiento para VIH/SIDA [press release]. Aug 5. Buenos Aires: OPS/MSAN; 2005.

16. Marin N, Osorio-de-Castro C. Información sobre negociación de precios ARV: Argentina, Paraguay, Uruguay. Informe técnico. Rio de Janeiro: OPS, NAF-ENSP/Fiocruz; 2005.

17. Seoane Vázquez E, Rodríguez-Monguió R. Análisis del impacto de la negociación de precios de medicamentos y reactivos para el VIH/ SIDA en los países Andinos. Informe técnico. Washington: Organización Pan Americana de la Salud; 2005.

18. Global AIDS Program. Monitoring and evaluation capacity building for program improvement. Field guide. Version 1. Atlanta: U.S. Centers for Disease Control and Prevention; 2003.

19. Chequer P, Cuchí P, Mazin R, García Calleja, $\mathrm{JM}$. Access to antiretroviral treatment in Latin American countries and the Caribbean. AIDS. 2002;16 Suppl 3:S50-7.

20. Marin N, Luiza VL, Osorio-de-Castro CGS, Machado-dos-Santos S, organizadores. Assistência farmacêutica para gerentes municipais. Rio de Janeiro: OPAS/OMS; 2003.

21. Management Sciences for Health; Euro Health Group. Economics for drug management. In: Managing drug supply. The selection, procurement, distribution, and use of pharmaceuticals. Hartford (CT): Kumarian Press; 1997. p. 36.

22. Piola SF, Vianna SM. Economia da saúde: conceito e contribuição para a gestão da saúde. $3^{\text {a }}$ ed. Brasília: IPEA; 1995. p. 5-21.

23. World Health Organization; Health Action International. Measuring medicine prices, availability, affordability and price components. 2nd ed. Geneva: WHO/HAI; 2003.

24. Galárraga O, O’Brien ME, Gutiérrez JP, Renaud-Théry F, Nguimfack BD, Beusenberg $\mathrm{M}$, et al. Forecast of demand for antiretroviral drugs in low and middle-income countries: 2007-2008. AIDS. 2007;21 Suppl 4:S97-103.

25. Chen HT. Theory driven evaluations. Newbury Park (CA): Sage Publications; 1990.

26. Hartz ZMA. Avaliação dos programas de saúde: perspectivas teórico metodológicas e políticas institucionais. Rev C S Col. 1999;4(2): 341-53. region is therefore recommended for incountry self-evaluation of ARV price negotiations implementation.
27. Dionisio D, Fabbri C, Messeri D. HIV drug policies and South markets: settling controversies. Therapy. 2008;5(5):707-17.

28. Vasan A, Hoos D, Mukherjee JS, Farmer PE, Rosenfield AG, Perriëns JH. The pricing and procurement of antiretroviral drugs: an observational study of data from the Global Fund. Bull World Health Organ. 2006;84(5):393-8. Epub 2006 May 17.

29. World Health Organization. A model quality assurance system for procurement agencies. Recommendations for quality assurance systems focusing on pre-qualification of products and manufacturers, purchasing, storage and distribution of pharmaceutical products. Geneva: WHO; 2007 [cited 2008 Apr 10]. (WHO/PSM/PAR/2007.3). Available from: www.who.int/medicines/publications/Mod elQualityAssurance.pdf.

30. Pan American Health Organization. Primera reunión del Grupo de Acompañamiento de las Negociaciones de Antiretrovirales (GAN/ ARV). Informe. Washington: PAHO; 2006 [cited 2008 Apr 18]. Available from: http:// www.paho.org/Spanish/AD/FCH/AI/ Informe_GAN_Dic_12_revisadonelly.pdf.

31. Kyomuhangi L. Prospects for financial sustainability of scaling up antiretroviral therapy programs. Health Pol Develop. 2005;3(2): 154-64

32. Boulet P, Garrison C, Hoen E. Drug patents under the spotlight: sharing practical knowledge about pharmaceutical patents. Geneva: Médecins sans Frontières; 2003.

33. Luiza VL, Osorio-de-Castro CGS, Nunes JM. Aquisição de medicamentos no setor público: o binômio qualidade-custo. Cad. Saúde Pública. 1999;15(4):769-76.

34. Global Fund to Fight AIDS, Tuberculosis \& Malaria [Internet]. Purchase price report. Geneva: GFATM; c2002-2009 [cited 2008 Dec 18]. Available from: http://web.the globalfund.org/ReportServer/Pages/Report Viewer.aspx?/PRM/Product+Price+Report.

35. World Health Organization [Internet]. Global price reporting mechanism. Geneva: WHO; 2008 [cited 2008 Dec 18]. Available from: http://www.who.int/hiv/amds/price/hdd/.

36. World Health Organization. Transaction prices for antiretroviral medicines and HIV diagnostics from 2004 to September 2008. Geneva: WHO; 2008.

Manuscript received on 18 June 2008. Revised version accepted for publication on 11 January 2009. 
RESUMEN Objetivo. La diseminación del VIH/sida exige de los gobiernos suministrar el tratamiento antirretroviral (ARV) a precios asequibles y se han desarrollado varias iniciativas con ese fin. En América Latina y el Caribe se han realizado cuatro negocia-

\section{Propuesta de metodología para monitorear la negociación de precios de los medicamentos antirretrovirales en América Latina y el Caribe} ciones subregionales entre 2002 y 2005 para reducir los precios de los medicamentos y así ampliar el acceso a los ARV. Se han realizado estudios para monitorear las negociaciones y se ha propuesto crear una metodología de monitoreo. El objetivo del presente trabajo fue desarrollar y describir una posible metodología para el monitoreo de las negociaciones de los precios de los ARV.

Métodos. El estudio, realizado en 2006-2007, constó de las fases de diseño y validación. En la fase de diseño se hizo una extensa revisión de la literatura y se desarrolló un marco teórico. La validación se realizó mediante un análisis de consenso de profesionales de la salud y un estudio piloto en tres países - Barbados, Honduras y Perúen representación del Caribe, América Central y la subregión andina.

Resultados. Se obtuvo un detallado modelo logístico y un marco conceptual de 40 indicadores. Ambos se probaron en el terreno. Se evaluaron la factibilidad, pertinencia y sensibilidad de los indicadores según los resultados del estudio piloto.

Conclusiones. Esta metodología de monitoreo se diseñó para ayudar a los países a autoevaluar sus progresos en la implementación de la negociación de precios de los ARV. Los resultados del estudio piloto indican que su implementación en el terreno ayudó a esclarecer el proceso de negociación de los precios de los ARV mediante la identificación de las condiciones locales y la medición indirecta de la capacidad de negociación de los países.

Palabras clave Agentes anti VIH; costos en medicamentos; política nacional de medicamentos; América Latina; Región del Caribe. 